\title{
The Evaluation on Green Mine Construction Level of Fanshan Phosphate in Hebei Province
}

\author{
Qing-Jun ZHANG ${ }^{1, a}$ * \\ ${ }^{1}$ School of Tourism and Geography, Shaoguan University, China \\ a1437594004@qq.com
}

\begin{abstract}
Keywords: Green mine;Evaluation index system;Construction standard;Fanshan phosphate
Abstract. The construction of green mine is a great action which wants to ease the pressure on the supply of mineral resources and the geological environment. According to "the basic conditions of national green mine", the evaluation system of constructing green mine is built, it includes 25 indexes of 8 categories, such as mining operation according to law, standardized management, etc. The construction level of green mine is divided into five grades which include excellent, good, moderate, general and poor. The multi-factor comprehensive evaluation method and the AHP method are adopted to evaluate on the construction level of green mine of Fanshan phosphate mine. The evaluation result indicates that the green mine construction level is good. Based on the above research, the corresponding countermeasures are put forward.
\end{abstract}

\section{Introduction}

At present, it is at a critical stage of rapid industrialization in China, the need of resources is rapidly increasing. On the one hand, the development and use of mineral resources effectively support the economic and social development; and on the other hand, the development and use model is still relatively extensive, mining environmental problems are increasingly severe. The main purpose of green mine aims at easing the pressure on the supply of mineral resources and the geological environmental. It has become a hot research field that building green mine evaluation system and estimating green mine construction level.Xuefeng Song evaluated green mine construction level of Xintianling tungsten mine in Hunan province by fuzzy mathematics comprehensive evaluation method[1].Mingxu Wang applied the new barrel theory to evaluate the level of green mine construction[2].The existing research has achieved initial results, but it needs to be further. In this paper, the multi-factor comprehensive evaluation method is used to evaluate the level of green mine construction of Fanshan phosphate, it will help mining enterprises promote the green mine construction process.

\section{Study Area and Data Sources}

Study Area.The Fanshan phosphate is located $30 \mathrm{~km}$ southeast of Zhuolu county in Hebei Province. The geographical coordinates of mining area centre is longitude $115^{\circ} 26^{\prime} 20$ " and latitude $40^{\circ} 10^{\prime} 20^{\prime \prime}$. The mining area is $2.153 \mathrm{~km}^{2}$. It is the only major phosphate of North China. The mine is divided into eastern district and western district. In 2014, the Fanshan phosphate became the fourth batch of pilot units of national green mines.

Data Sources.Basic data is from field research and statistical data, the other data is obtained from the Fanshan phosphate.

\section{Green Mine Construction Level Evaluation}

Construction of Green Mine Evaluation Index System. According to the " the basic conditions of national green mine " issued by the Ministry of Land and the "green mining convention" drafted by China Mining Association, and based on the AHP method, the index system is divided into three rating of goal level, rule level, index level. The rule level comprises eight aspects of mining operation 
criterion according to law, standardized management, comprehensive use, technological innovation, energy conservation and emission reduction, environmental protection, land reclamation, business and society harmony, the index level contains 25 specific indexes, the result is shown in table 1 .

Table 1 the green mine evaluation system of the Fanshan phosphate

\begin{tabular}{|c|c|c|}
\hline Goal level A & Rule level B & Index level $\mathrm{C}$ \\
\hline \multirow{25}{*}{$\begin{array}{c}\text { green mine } \\
\text { construction } \\
\text { level } \\
\text { evaluation }\end{array}$} & \multirow{4}{*}{$\begin{array}{c}\text { mining } \\
\text { operation in } \\
\text { accordance with } \\
\text { law } \mathrm{B}_{1}\end{array}$} & License status $\mathrm{C}_{1}$ \\
\hline & & Taxes and deposit paid circumstances $\mathrm{C}_{2}$ \\
\hline & & Relevant administrative punishment case within three years $\mathrm{C}_{3}$ \\
\hline & & Number of programs through a review $\mathrm{C}_{4}$ \\
\hline & \multirow{3}{*}{$\begin{array}{c}\text { standardized } \\
\text { management } \mathrm{B}_{2}\end{array}$} & Green mine construction plan and implementation $\mathrm{C}_{5}$ \\
\hline & & $\begin{array}{l}\text { Development, environmental protection, land reclamation, safety } \\
\text { and other regulations perfection circumstances } \mathrm{C}_{6}\end{array}$ \\
\hline & & Safety, environmental and quality certification status $\mathrm{C}_{7}$ \\
\hline & \multirow{3}{*}{$\begin{array}{c}\text { comprehensive } \\
\text { use } \mathrm{B}_{3}\end{array}$} & Comprehensive use advancement $\mathrm{C}_{8}$ \\
\hline & & Advanced technical and economic levelC $\mathrm{C}_{9}$ \\
\hline & & "Three rate" index advancement $\mathrm{C}_{10}$ \\
\hline & \multirow{2}{*}{$\begin{array}{c}\text { technical } \\
\text { innovation } \mathrm{B}_{4}\end{array}$} & Technical innovation funding ratioC $\mathrm{C}_{11}$ \\
\hline & & Advanced production technology $\mathrm{C}_{12}$ \\
\hline & \multirow{2}{*}{$\begin{array}{l}\text { conserving } \\
\text { energy and } \\
\text { reducing } \\
\text { emissions } \mathrm{B}_{5}\end{array}$} & Energy saving and emission reduction status $\mathrm{C}_{13}$ \\
\hline & & "Three wastes" status $\mathrm{C}_{14}$ \\
\hline & \multirow{4}{*}{$\begin{array}{l}\text { environmental } \\
\text { protectionB }_{6}\end{array}$} & $\begin{array}{l}\text { The "three simultaneous implementation" system of } \\
\text { environmental protection } \mathrm{C}_{15}\end{array}$ \\
\hline & & Mine environmental protection and management recovery planC $\mathrm{C}_{16}$ \\
\hline & & The incidence of geological disasters $\mathrm{C}_{17}$ \\
\hline & & Greening coverage ratio in mine $\operatorname{areaC}_{18}$ \\
\hline & \multirow{3}{*}{$\begin{array}{l}\text { land } \\
\text { reclamationB }\end{array}$} & Land reclamation program $\mathrm{C}_{19}$ \\
\hline & & Land reclamation technology advancement $\mathrm{C}_{20}$ \\
\hline & & Land reclamation rateC 21 \\
\hline & \multirow{4}{*}{$\begin{array}{l}\text { enterprise and } \\
\text { society } \\
\text { harmonyB }\end{array}$} & The social image of enterprise $\mathrm{C}_{22}$ \\
\hline & & The quality of business leaders and workers $\mathrm{C}_{23}$ \\
\hline & & Staff technical training system soundness $\mathrm{C}_{24}$ \\
\hline & & $\begin{array}{l}\text { Improvement of the mechanism of consultation and } \\
\text { coordination } C_{25}\end{array}$ \\
\hline
\end{tabular}

Evaluation Index Value Determining Criteria. At present, there is no uniform standard to determine evaluation index value. The following methods are often adopted to determine the evaluation index value: 1 ) according to the " the basic conditions of national green mine", such as technological innovation, funding for technological innovation each year is not less than $1 \%$ of the total output value of mining enterprise; such as environmental protection, the greening coverage ratio should reach more than $80 \%$ and so on. 2) according to the "national mineral resource master plan (2008-2015)", the state local norms and standards, such as "encourage, restrict and eliminate technique directory of conservation and comprehensive use of mineral resources" (Guotu zifa [2010] No. 146) issued by the Ministry of Land. 3) adopting the highest value of technical index of the same type of mine. 4) according to the existing research results[1-7] . 5) consulting to the relevant mining experts.

We could use the above methods to determine the evaluation index value, the value and standard of index are as follows:

1) the index $\mathrm{C}_{1}$ : completion of mining permits license, safe production license and other permits license $(90 \sim 100)$; extension handle of a single license $(80 \sim 89)$; extension handle of two license 
(70 79); no handle of single license $(60 \sim 69)$; no handle of more than two licenses $(<60)$.

2 ) the index $\mathrm{C}_{2}$ : timely and full payment of taxes and margin $(90 \sim 100)$; not pay the full taxes and margin (80 89); a not timely paid(70 79); two not timely paid(60 69$)$; long-term arrears $(<60)$.

$3)$ the index $\mathrm{C}_{3}$ : not receive any punishment executive $(90 \sim 100)$; one time penalties $(80 \sim 89)$; two time penalties $(70 \sim 79)$; three time penalties $(60 \sim 69)$; more than three times penalties $(<60)$.

4) the index $\mathrm{C}_{4}$ : with "mineral resources development and utilization planning", "mine geological environment protection and recovery planning", "land reclamation planning", "green mine construction planning" and other programs $(90 \sim 100)$;lack of a program(80 89); lack of two $\operatorname{program}(70 \sim 79)$; lack of three program $(60 \sim 69)$; missing three or more programs $(<60)$.

5) the index $\mathrm{C}_{5}$ : the planning is practicable, operability is very strong, and the effect is significant(90 100); the planning has some difficulties, it is easy to operate, and the effect is the better( $80 \sim 89)$; the planning has more difficulties, operability is general, and the effect is general(70 79); the planning is very difficult, operability is general, and the effect is general(60 69); the program is general, feasibility is general, and the effect is not significant $(<60)$.

$6)$ the index $C_{6}$ : the system has integrity and strong operability $(90 \sim 100)$;various rules and regulations are more complete and workable $(80 \sim 89)$; rules and regulations are missing, the operability is general $(70 \sim 79)$;seriously lack of rules and regulations, the operability is poor $(60 \sim$ 69); no regulations $(<60)$.

7) the index $C_{7}$ : certification authority for all $(90 \sim 100)$; there is a no certification authority $(80 \sim$ 89); there are two without certification $(70 \sim 79)$; there are three without certification $(60 \sim 69)$; they do not get the relevant certification $(<60)$.

$8)$ the index $\mathrm{C}_{8}$ : leading in domestic industry $(90 \sim 100)$; more advanced in domestic industry( $80 \sim$ 89 ); advanced in domestic industry(70 79); general in domestic industry $(60 \sim 69)$; behind in domestic industry $(<60)$.

9) the index $\mathrm{C}_{9}$ : technical and economic level is leading in domestic industry $(90 \sim 100)$; technical and economic level is advanced in domestic industry(80 89);technical and economic level is relatively advanced in domestic industry(70 79); technical and economic level is general in domestic industry $(60 \sim 69)$;technical and economic level is behind $(<60)$.

10) the index $C_{10}$ : "three rate" index is leading in domestic industry $(90 \sim 100)$; it is more advanced in the domestic industry $(80 \sim 89)$; it is advanced in industry $(70 \sim 79)$; it is general in industry( $60 \sim$ 69); it is behind in industry $(<60)$.

11) the index $C_{11}$ : technical innovation funding ratio is higher than $4 \%$ ( $\left.90 \sim 100\right)$; technical innovation funding ratio is between $3 \%$ to $4 \%(80 \sim 89)$; technical innovation funding ratio is between $2 \%$ and $2 \%(70 \sim 79)$; technical innovation funding ratio is between $1 \%$ and $2 \%(60 \sim 69)$; technical innovation funding ratio is less than $1 \%(<60)$.

12) the index $\mathrm{C}_{12}$ : production technology is industry-leading in domestic, innovation is strong(90 $100)$; production technology is more advanced in industry, and innovation is strong $(80 \sim 89)$; production technology is advanced in industry, innovation is strong $(70 \sim 79)$;production technology is general, innovation is general $(60 \sim 69)$; technical process is general, innovation is $\operatorname{poor}(<60)$.

13) the index $C_{13}$ : conserving energy per year conform to the national standard $(90 \sim 100)$; there is a year in which it did not meet the national standard $(80 \sim 89)$; there are two years in which it did not meet the national standard(70 79); there are three years in which it did not meet the national standard $(60 \sim 69)$; it did not meet the national standard for more than three years $(<60)$.

14) the index $C_{14}$ : three wastes" emissions meet standards each year(90 100); there is a year in which it did not meet the national standard $(80 \sim 89)$; there are two years in which it did not meet the national standard $(70 \sim 79)$; there are there years in which did not meet the national standard $(60 \sim$ $69)$;it did not meet the national standard for more than three years $(<60)$. 
15) the index $\mathrm{C}_{15}$ : strict implementation of environmental protection "three simultaneous" system, mining environment is very $\operatorname{good}(90 \sim 100)$; able to perform environmental protection "three simultaneous" system, the effect is better(80 89);able to perform environmental protection "three simultaneous" system, effect is $\operatorname{good}(70 \sim 79)$;able to perform environmental protection "three simultaneous" system, the effect is general(60 69);not able to perform environmental protection "three simultaneous" system $(<60)$.

16) the index $C_{16}$ : program is feasible, operability is very strong, and the effect is significant $(90 \sim$ $100)$; there are some difficulties, it is easy to operate, and the effect is $\operatorname{good}(80 \sim 89)$; there are more difficulties, it is easy to operate, and the effect is general(70 79); there are more difficult, it is general to operate, and the effect is general(60 69);program is general, feasibility is general, and the effect is not significant $(<60)$.

17) the index $C_{17}$ : no major geological disasters occurrence within three years $(90 \sim 100)$;one major geological disasters occurrence within three years $(80 \sim 89)$;two major geological disasters occurrence within three years $(70 \sim 79)$; three major geological disasters occurrence within three years $(60 \sim$ 69); more than three major geological disasters within three years $(<60)$.

18) the index $\mathrm{C}_{18}: 80 \%$ and above $(90 \sim 100) ; 70 \% \sim 80 \%(80 \sim 89) ; 60 \% \sim 70 \%(70 \sim 79) ; 50 \% \sim$ $60 \%(60 \sim 69)$; less than $50 \%(<60)$.

19) the index $\mathrm{C}_{19}$ : program is feasible, operability is very strong and the effect is significant $(90 \sim$ $100)$; there are some difficulties, it is easy to operate and the effect is better( $80 \sim 89)$; there are more difficult, operability is general and the effect is general(70 79);program is very difficult, operability is general and the effect is general $(60 \sim 69)$;program is general, feasibility is general and the effect is not significant $(<60)$.

20) the index $\mathrm{C}_{20}$ : land reclamation technology is leading in domestic and reclamation works are well(90 100); land reclamation technology is more advanced, reclamation effect is better(80 $89)$; land reclamation technology is advanced, reclamation effect is $\operatorname{good}(70 \sim 79)$; land reclamation technology is general, reclamation effect is general $(60 \sim 69)$; land reclamation technology is poor, reclamation effect is poor $(<60)$.

$21)$ the index $C_{21}$ :leading in similar mines $(90 \sim 100)$; advanced in similar mine $(80 \sim 89)$; relatively advanced in similar mine(70 79); general in similar mine(60 69); behind in similar mine $(<60)$.

22) the index $\mathrm{C}_{22}$ : earnestly fulfill their social responsibility, with a high corporate image $(90 \sim$ $100)$; better fulfill their social responsibilities, with a high corporate image( $80 \sim 89)$;able to fulfill their social responsibility, with a corporate image $(70 \sim 79)$; able to fulfill part of social responsibility, with certain corporate image $(60 \sim 69)$; not fulfill their social responsibility, corporate image is general $(<60)$.

23) the index $\mathrm{C}_{23}$ : enterprise leaders are very efficient, workers are very high-quality( $90 \sim$ 100); enterprise leaders are efficient, workers are high-quality $(80 \sim 89)$; enterprise leaders are general, workers are general( $70 \sim 79)$; enterprise leaders are acceptably efficiency, the quality of workers is acceptable(60 69); enterprise leaders are efficient and quality of staff are to be improved $(<60)$.

$24)$ the index $C_{24}$ : staff technical training system is very well with good results $(90 \sim 100)$;staff technical training system is more comprehensive and effective $(80 \sim 89)$;staff technical training system is general with the general effect(70 79); staff technical training system is general with the general effect $(60 \sim 69)$; staff technical training system is not perfect $(<60)$.

25 ) the index $\mathrm{C}_{25}$ : consultation and coordination system is perfect, they have a good solution to the enterprise and social conflicts(90 100); consultation and coordination system are good, they have a good solution to the enterprise and social conflicts $(80 \sim 89)$; consultation and coordination system are general, they have a good solution to the enterprise and social conflicts(70 79$)$; consultation and 
coordination system are general, it can solve some enterprise and social conflicts (60 69); lack of consultation and coordination mechanism $(<60)$.

Determination of Index Weights. The index weight is determined by Delphi method. Delphi method is a method that an expert group reach a consensus about the degree of importance about a particular index in the case that the individual members do not communicate with each other. 20 experts are invited, including from land system and some universities. The scoring is divided into two rounds. After the first round of scoring, we publish the results and announce the average value and the standard differential, and then the second round of scoring begins based on the results of the first round of scoring. Thus, after two rounds, the opinion of the weight tends consistent. Thereby we arrive at a more reliable measurement results, It is shown in table 3.

Comprehensive Value Calculation of Green Mine Construction. Rule layer score calculation. The rule level score is calculated by the following Eq.1:

$$
F_{j}=\sum_{k=1}^{n}\left(S_{j k} \times W_{j k}\right)
$$

Where: $F_{j}-$ Green mine construction level score of rule layer $\mathrm{j} ; \mathrm{S}_{\mathrm{jk}}-\mathrm{K}$ indicator score of rule layer $\mathrm{j} ; \mathrm{W}_{\mathrm{jk}}$ —Weight value of $\mathrm{K}$ indicator of rule layer $\mathrm{j}$ opposite rule layer $\mathrm{j} ; \mathrm{n}$ number of indicators 。

Score of goal layer calculation. The goal layer value is calculated by the following Eq.2:

$$
F=\sum_{j=1}^{n}\left(F_{j} \times W_{j}\right)
$$

Where: $\mathrm{F}$ - Green mine construction level scores of target layer; $\mathrm{F}_{\mathrm{j}}$ - Green mine construction score of rule layer $\mathrm{j} ; \mathrm{W}_{\mathrm{j}}$-Weight values of rule layer $\mathrm{j}$ relative to the goal layer; $\mathrm{n}$ - The number of goals。

\section{Evaluation Result and Analysis}

Evaluation Results. Survey data about mineral development, environmental protection, land reclamation and production safety are collected in the Fanshan phosphate, experts of the land system are invited to score the index, and integrated value of green mine construction level is calculated, the process and result are shown in table 2 
Table 2The green mine construction evaluation process and result of the Fanshan phosphate

\begin{tabular}{|c|c|c|c|c|c|}
\hline $\begin{array}{c}\text { Goal layer } \\
\text { (score) }\end{array}$ & $\begin{array}{c}\text { Rule layer } \\
\text { (score) }\end{array}$ & Weights & Index layer & Weights & Score \\
\hline \multirow{25}{*}{$\begin{array}{c}\mathrm{A} \\
(88.17)\end{array}$} & \multirow{4}{*}{$\begin{array}{c}\mathrm{B}_{1} \\
(90)\end{array}$} & \multirow{4}{*}{0.1500} & $\mathrm{C}_{1}$ & 0.3000 & 90 \\
\hline & & & $\mathrm{C}_{2}$ & 0.2500 & 90 \\
\hline & & & $\mathrm{C}_{3}$ & 0.2500 & 90 \\
\hline & & & $\mathrm{C}_{4}$ & 0.2000 & 90 \\
\hline & \multirow{3}{*}{$\begin{array}{c}\mathrm{B}_{2} \\
(86.5)\end{array}$} & \multirow{3}{*}{0.1500} & $\mathrm{C}_{5}$ & 0.3000 & 90 \\
\hline & & & $\mathrm{C}_{6}$ & 0.4500 & 85 \\
\hline & & & $\mathrm{C}_{7}$ & 0.2500 & 85 \\
\hline & \multirow{3}{*}{$\begin{array}{c}\mathrm{B}_{3} \\
(88.5)\end{array}$} & \multirow{3}{*}{0.2000} & $\mathrm{C}_{8}$ & 0.3000 & 85 \\
\hline & & & $\mathrm{C}_{9}$ & 0.3500 & 90 \\
\hline & & & $\mathrm{C}_{10}$ & 0.3500 & 90 \\
\hline & \multirow{2}{*}{$\begin{array}{c}\mathrm{B}_{4} \\
(92.25) \\
\end{array}$} & \multirow{2}{*}{0.1000} & $\mathrm{C}_{11}$ & 0.4500 & 95 \\
\hline & & & $\mathrm{C}_{12}$ & 0.5500 & 90 \\
\hline & \multirow{2}{*}{$\begin{array}{c}\mathrm{B}_{5} \\
(87.5) \\
\end{array}$} & \multirow{2}{*}{0.1500} & $\mathrm{C}_{13}$ & 0.5000 & 85 \\
\hline & & & $\mathrm{C}_{14}$ & 0.5000 & 90 \\
\hline & \multirow{4}{*}{$\begin{array}{c}\mathrm{B}_{6} \\
(87.75)\end{array}$} & \multirow{4}{*}{0.1000} & $\mathrm{C}_{15}$ & 0.3000 & 90 \\
\hline & & & $\mathrm{C}_{16}$ & 0.2500 & 90 \\
\hline & & & $\mathrm{C}_{17}$ & 0.2500 & 85 \\
\hline & & & $\mathrm{C}_{18}$ & 0.2000 & 85 \\
\hline & \multirow{3}{*}{$\begin{array}{c}\mathrm{B}_{7} \\
(86.5)\end{array}$} & \multirow{3}{*}{0.1000} & $\mathrm{C}_{19}$ & 0.3500 & 85 \\
\hline & & & $\mathrm{C}_{20}$ & 0.3500 & 85 \\
\hline & & & $\mathrm{C}_{21}$ & 0.3000 & 90 \\
\hline & \multirow{4}{*}{$\begin{array}{c}\mathrm{B}_{8} \\
(84)\end{array}$} & \multirow{4}{*}{0.0500} & $\mathrm{C}_{22}$ & 0.2500 & 85 \\
\hline & & & $\mathrm{C}_{23}$ & 0.3000 & 85 \\
\hline & & & $\mathrm{C}_{24}$ & 0.2500 & 85 \\
\hline & & & $\mathrm{C}_{25}$ & 0.2000 & 80 \\
\hline
\end{tabular}

Results and Analysis. According to the "national green mines basic conditions", green mine construction level is divided into five levels including excellent, good, moderate, general and poor, each level with corresponding score is shown in table 3

Table 3the green mine construction level standards

\begin{tabular}{|l|l|l|}
\hline Number & Green mine construction level & Score \\
\hline 1 & Excellent & $90 \sim 100$ \\
\hline 2 & Well & $80 \sim 90$ \\
\hline 3 & Moderate & $70 \sim 80$ \\
\hline 4 & General & $60 \sim 70$ \\
\hline 5 & Poor & $<60$ \\
\hline
\end{tabular}

Based on the above method, the evaluation score of the Fanshan phosphate is 88.17 , it belongs to the level of good. In addition to mining operation in accordance with law and technology innovation of rule layer are excellent, the other six aspects are good. Aspects which are needed to be improved include: the specification management, the Fanshan phosphate needs further refinement to improve the operability. In the comprehensive use, the Fanshan phosphate tailings need to fill mined area, secondary use of tailings needs to be improved. In terms of conserving energy and reducing emissions, we should increase the proportion of clean energy to reduce energy consumption per unit of product. About land reclamation, the scope of the depressed region is expanding with production, land 
reclamation is more difficult, it affects the evaluation scores. In the corporate and society harmony, staff technical training system needs to be refined. The consultation and cooperation mechanism between enterprise and the surrounding community needs innovation.

\section{Acknowledgements}

This work was financially supported by the undergraduate teaching quality and teaching reform project building of a professional comprehensive reform - tourism management in Guangdong Province in 2014 (Yue Jiao Gao Han [2014]97).

\section{References}

[1] Xuefeng Song, Bin Wen, in:China Mining Magazine,Vol.(23)(2013),p.54-56,61.

[2] Mingxu Wang, Mengguo Xu,Ping Wang, Bin Li,Mingde Zhu,Feng Xie,in:China Mining Magazine,Vol.(22)(2013),p.68-72.

[3] Jingjun Huang, Yunfei Song, Yujun Wang, Jiazeng Ni, Zijun Xu, Tieqin Guan,in:China Mining Magazine,Vol.(19)(2010),p.79-80,81.

[4] Jingjun Huang, Jiazeng Ni, Yongzhong Zhao, Yunfei Song, Gu Zhu,in: China Mining Magazine, Vol.(17)(2008),p.36-39.

[5] Jingjun Huang, Jiazeng Ni, Yunfei Song, Yujun Wang,Gu Zhu,in:Metalmine,(2009),p.147-150.

[6] Zhigang Yan,Yuping Liu,Xueli Wang,in:China Coal, Vol.(38)(2012),p.116-120.

[7] Deming Zhang, in:Recyclable Resources and Cyclular Economy, Vol.(3)(2010),p.11-13. 